\title{
Indexes of Natural Selection, Migration and Reproductive Characteristics in Lutsk Population, West Ukraine
}

\author{
N. Kozak and L. Atramentova
}

\begin{abstract}
In human populations natural selection is shifting to the side of prenatal development and appears as negative outcomes of pregnancies such as spontaneous abortions, ectopic pregnancies and stillbirths. Therefore, it is important to study dynamics of changes in reproductive characteristics and selection indexes of the populations in order to predict possible problems and numbers of genetic burden in the populations. Ukraine is poorly studied in this area. The aim of the study was to investigate indicators which characterize the population structure of Lutsk city, the intensity of natural selection, migration and their dynamics in two generations. 583 postreproductive age females were anonymously questioned. Age, places of birth of the couple, the number of pregnancies and their outcomes were considered. Results show that natural selection indexes (Crow's indexes) are decreasing from the first generation $(0,26)$ to the second $(0,20)$. Migration coefficients in the population of Lutsk decreased from 0.89 to 0.82 per generation and show intensive urbanization of the city for the studied time. The efficiency of the migration is low, since the biggest number of migrants come from the villages of the Volyn region (45\% for first generations and $64 \%$ for the second one), or adjacent regions of Ukraine (35\% and $27 \%$, respectively). The population of Lutsk has a narrowed type of reproduction, where average number of offspring per female equal 1,86 for the first generation and 1,73 for the second generation.
\end{abstract}

Key words - Crow's index; generations; Lutsk population; reproductive characteristics; selection.

\section{INTRODUCTION}

The reproductive behavior of women depends on their nationality, religion and other social factors, forming the type of population reproduction, which affects its gene pool [1], [2]. The population of Ukraine is ethnically heterogeneous, since in different periods of history, different regions of the country were parts of different kingdoms and principalities [3].

Lutsk is one of the oldest cities in Ukraine, founded around $1000 \mathrm{AD}$. It is the administrative center of the Volyn region. The formation of settlements in this region has been known since the Neolithic period [4]. Throughout the history of the city, Ukrainians, Poles, Jews, Karaites contributed to the gene pool of the population [5], [6], and during the period when Ukraine was part of the USSR, the percentage of Russians was increasing too [5].

The aim of this research was to obtain indicators characterizing the population structure of Lutsk city, the intensity of natural selection, migration and their dynamics in

Published on October 25, 2021

N. Kozak, V.N. Karazin Kharkiv National University, Ukraine

(e-mail: kozaknatali93@gmail.com) two generations.

\section{Materials AND Methods}

The material was collected in 2018 in the city polyclinics of Lutsk: "Lutsk Center for Primary Medical and Sanitary Assistance" and "Lutsk Center for Primary Medical and Sanitary Assistance No. 2". A voluntary anonymous survey of women of post-reproductive age was conducted. The questionnaire included questions about the woman's place of birth and her husband's one, year of birth, education, her ethnicity and ethnicity of her parents, also the number of pregnancies and their outcomes were taken into account: the number of medical abortions and how many of them were done for medical reasons, spontaneous abortions, ectopic pregnancies, stillbirths and live births, and whether the newborn children had congenital developmental pathologies. The total number of collected questionnaires were 583 .

The surveyed were divided into two generations for studies of the dynamics of selection processes and changes in reproductive and migration processes. Women who was born in 1925-1952 were attributed to the first generation, those who was born in 1953-1978 were included into the second one.

General significant statistics were calculated, natural selection indexes were calculated according to J. Crow (1954) (cited from [7]). Also, migration rate, marital distance, parent-offspring distance have been calculated. The marital distance was calculated between the birthplaces of a married couple using the Google maps API. Differential mortality rates were obtained from [8], [9]. Comparison of arithmetic means was carried out using the $t$ test. The percentage were compared by $\varphi$-transformation using the $F$ test. Null statistical hypotheses were tested at a significance level of $<0.05$ with Bonferroni's correction for multiple comparisons.

\section{RESUltS AND Discussion}

A. Reproductive Characteristics and Selection Index in Two Generations

The number of pregnancies in women of the first generation varies from 0 to 13 , in women of the second generation from 0 to 17 . The average number of pregnancies and their outcomes in women of Lutsk population between the first and second generations did not reach the level of

L. Atramentova, V.N. Karazin Kharkiv National University, Ukraine. (e-mail: lubov.atramentova@gmail.com) 
statistical significance, except for two parameters which are live births and childbirth (Table I). Women of the first generation had larger number of children compared to the second generation, however, the average number of children in Lutsk families indicates a narrowed type of reproduction of the given population. The number of consciously regulated indicators (pregnancies, medical abortions and childbirths) decreased in the second generation, which can be associated with the improvement in the quality of medical services and artificial family planning. The number of non-regulated indicators (spontaneous abortions, ectopic pregnancies and stillbirths) did not change.

TABLE I: AVERAGE NUMBER OF PREgNANCIES AND THEIR OUTCOMES PER A WOMAN

\begin{tabular}{|c|c|c|c|c|c|c|c|}
\hline \multirow{3}{*}{ Index } & \multicolumn{6}{|c|}{ Generations } & \multirow{3}{*}{$p$} \\
\hline & \multicolumn{3}{|c|}{$f_{l}(n=203)$} & \multicolumn{3}{|c|}{$f_{2}(n=383)$} & \\
\hline & $\overline{\mathrm{x}}$ & $M e$ & $M o$ & $\overline{\mathrm{x}}$ & $M e$ & Mo & \\
\hline Pregnancies & 3.58 & 3.0 & 2.0 & 3.39 & 3.0 & 3.0 & $>0.05$ \\
\hline Medical abortions & 1.42 & 1.0 & 0.0 & 1.34 & 1.0 & 0.0 & $>0.05$ \\
\hline Med. abort. by med. reasons & 0.06 & 0.0 & 0.0 & 0.14 & 0.0 & 0.0 & $>0.05$ \\
\hline Spontaneous abortions & 0.29 & 0.0 & 0.0 & 0.27 & 0.0 & 0.0 & $>0.05$ \\
\hline Ectopic pregnancies & 0.02 & 0.0 & 0.0 & 0.05 & 0.0 & 0.0 & $>0.05$ \\
\hline Stillbirths & 0.03 & 0.0 & 0.0 & 0.03 & 0.0 & 0.0 & $>0.05$ \\
\hline Live births & 1.82 & 2.0 & 2.0 & 1.70 & 2.0 & 2.0 & $<0.05$ \\
\hline Congenital develop. pathologies & 0.03 & 0.0 & 0.0 & 0.04 & 0.0 & 0.0 & $>0.05$ \\
\hline Childbirths & 1.86 & 2.0 & 2.0 & 1.73 & 2.0 & 2.0 & $<0.05$ \\
\hline
\end{tabular}

Notes: $n$ - number of probands, $f_{1}-$ first generation, $f_{2}-$ second generation, $\overline{\mathrm{x}}-$ arithmetic mean, $M e-$ median,

$M o$ - mode, $p$ - significance level, Med. abort. by med. Reasons - medical abortions made by medical reasons. Congenital develop. pathologies - congenital developmental pathologies

Among women of the second generation, the percentage of abortions for medical reasons increased by 2.5 times and amounted to $10.4 \%$, compared with the first generation $(4.2 \%)$. The percentage of congenital malformations raised from $1.65 \%$ to $2.35 \%$. The growth of these indicators can be linked to the active industrialization of the city in the 60-70s of the XX century and active population growth due to high migration rate [6], as well as the proximity of the region to the Chernobyl Nuclear Power Plant.

TABLE II: DistRIBUTION OF PREGNANCY OUTCOMES IN WOMEN IN TWO GENERATIONS

\begin{tabular}{cccc}
\hline \hline Indicators & $\begin{array}{c}f_{1} \\
n=203\end{array}$ & $\begin{array}{c}f_{2} \\
n=383\end{array}$ & $p$ \\
\hline \hline Number of the females who: & 6.9 & 2.1 & $<0.01$ \\
did not have pregnancies (\%) & 8.4 & 4.7 & $>0.05$ \\
did not give birth (\%) & 57.1 & 59.3 & $>0.05$ \\
had medical abortions (\%) & 18.7 & 20.4 & $>0.05$ \\
had spontaneous abortions (\%) & 2.0 & 4.7 & $>0.05$ \\
had ectopic pregnancies (\%) & 3.4 & 2.9 & $>0.05$ \\
had stillbirth (\%) & 39.7 & 39.6 & $>0.05$ \\
Artificially terminated pregnancies & 51.0 & 50.2 & $>0.05$ \\
Realized zygotes &
\end{tabular}

Notes: $n$ - number of probands, $f_{1}-$ first generation, $f_{2}-$ second generation, $p$ - significance level.

The majority of women of the first (79\%) and second (84\%) generations had childbirth 1-2 times. Almost $7 \%$ of women of the first generation did not contribute to the genetic pool of the Lutsk population, in the second generation there were only $2 \%$ of them ( $p<0.01$, Table II). The share of nulliparous women decreased by 1.8 times from the first generation to the second ( $8.4 \%$ and $4.7 \%$, respectively).

Second-generation women were having slightly bigger percentage of medical abortions than first-generation women. The proportion of women who had spontaneous abortions and ectopic pregnancies also little bit increased in the second generation. In total, almost $40 \%$ of pregnancies were terminated artificially. The percentage of realized zygotes is $50-52 \%$. Lutsk population, where the majority of the inhabitants are ethnic Ukrainians, retains a greater number of pregnancies than, for example, Kharkiv [10], [11], Poltava
[12] and Moscow populations [13], which have larger number of Russians and other nationalities. But in comparison with the Muslims living on the territory of Ukraine, the share of realized zygotes in the Lutsk population is about $16 \%$ lower than that of the Muslim family of the Crimean Tatars [14].

TABLE III: CROW'S INDEXES IN TWO GENERATIONS

\begin{tabular}{ccc}
\hline \hline Indicators & $f_{1}$ & $f_{2}$ \\
\hline \hline $\bar{x}^{2}$ & 3.312 & 2.890 \\
$s^{2}$ & 0.792 & 0.578 \\
$I_{f}=s^{2} / \bar{x}^{2}$ & 0.239 & 0.200 \\
$p_{d}$ & 0.015 & 0.003 \\
$p_{s}$ & 0.985 & 0.997 \\
$I_{m}=p_{d} / p_{s}$ & 0.015 & 0.003 \\
$I_{f} / p_{s}$ & 0.244 & 0.201 \\
$I_{\text {tot }}=I_{m}+I_{f} / p_{s}$ & 0.259 & 0.204 \\
\hline \hline
\end{tabular}

Notes: $f_{l}-$ first generation, $f_{2}-$ second generation, $\overline{\mathrm{x}}-$ the average number of offspring per woman who survived till the end of reproductive age, $s^{2}-$ dispersion of the number of offspring, $I_{m}=p_{d} / p_{s}$ - selection component associated with differential mortality, $p_{d}$ - proportion of individuals who died before reproductive age, $p_{s}$ - proportion of individuals who survived to reproductive age, $I_{f}$ - selection component associated with differential fertility. $I_{\text {tot }}-$ total Crow's index

The vital characteristics of a population make it possible to estimate the pressure of natural selection, with the weakening of which the genetic load increases. According to [7], [10], [11], [15] in Ukrainian populations, the intensity of natural selection weakens from generation to generation, as in other developed countries with a low mortality rate [16], [17]. The Crow's index in Lutsk population decreased from 0.26 in the first generation to 0.20 in the second (Table III). The main role in this decrease is played by the differential mortality rate $I_{m}$. Its value decreases from 0.015 in the first generation to 0.003 in the second generation. The $I_{f}$ component of differential fertility decreased from 0.24 to 0.20 , respectively.

\section{B. Migration Characteristics}

Migration is one of the most powerful population processes affecting the structure of modern human populations. The efficiency of migration depends on the migration rate and the difference in allele frequencies between the donor and recipient populations. Studying migration rates is one of the 
ways to predict consequences.

TABLE IV: MIGRATION COEFFICIENTS

\begin{tabular}{ccccc}
\hline \hline \multirow{2}{*}{ Indicators } & \multicolumn{3}{c}{$f_{1}$} & \multicolumn{3}{c}{$f_{2}$} \\
\cline { 2 - 5 } & $n$ & $m$ & 383 & 0.80 \\
\hline For Females & 203 & 0.88 & 358 & 0.84 \\
For Males & 188 & 0.89 & 741 & 0.82 \\
Total & 391 & 0.89 & 0 \\
\hline \hline
\end{tabular}

Notes: $f_{l}-$ first generation, $f_{2}-$ second generation, $n-$ number of people, $m$ - migration coefficient

High migration rates indicate intensive urbanization in Lutsk city, but the efficiency of the migration is low, since most migrants come from the villages of the Volyn region, or adjacent regions of Ukraine. In one generation, the migration rate in the population of Lutsk decreased from 0.89 to 0.82 (Table IV), which coincides with the same trends in other cities of Ukraine [18], [19] and Russia [20].

According to the distance from the place of birth to Lutsk city, migrants were divided into three groups. Migrants from Lutsk region made up a group of Close Migrations. The group of those, who was born in other regions of Ukraine is designated as Intermediate, the natives of other countries are included in the group of Distant Migrants.

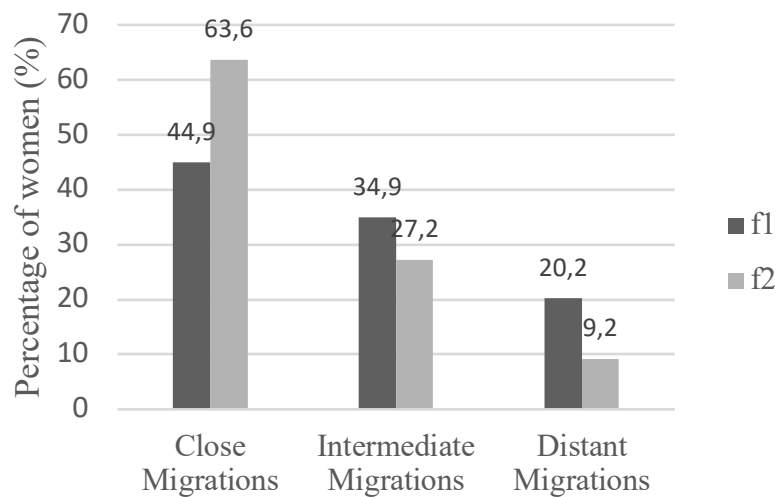

Fig. 1. Migration range in two generations: $\mathrm{f} 1$ - first generation, $\mathrm{f} 2$ - second generation.

According to the graph (Fig. 1), we can judge about the decrease in the number of migrants in the second generation in comparison with the first, as well as on the quality of migrants. So, in the first generation, the percentage of Close Migrants amounted to $45 \%$ of all migrants, and in the second generation, the number of such migrations reaches almost $64 \%$. Such data indicate that Lutsk population is in the process of active formation and corresponds to the model of metapopulations of large cities.

The percentage of migrants who married locals increased in 1.4 times over a generation: from $14 \%$ to $21 \%$. The share of marriages between migrants decreased from $81 \%$ to $72 \%$ $(\mathrm{p}<0.01$, Table V).

Isolation by distance is weakening due to the development of transport infrastructure. Changes in the number and quality of migrations are reflected in the genetic pool of populations. There were no statistically significant differences between the indicators noted in the Table VI, however, it is worth to point out that the number of medical abortions performed for medical reasons, ectopic pregnancies and the presence of malformations increases in Intermediate and Distant migrants, compared with Close migrants, which corresponds to the literature data.

TABLE V: MARITAL StRUCTURE ACCORDING TO THE PLACE

\begin{tabular}{|c|c|c|c|c|c|}
\hline \multirow{2}{*}{ Indicators } & \multicolumn{2}{|c|}{$f_{l}$} & \multicolumn{2}{|c|}{$\overline{f_{2}}$} & \multirow{2}{*}{$p$} \\
\hline & $n=188$ & $\%$ & $n=355$ & $\%$ & \\
\hline $\begin{array}{l}\text { Marriages between } \\
\text { natives of Lutsk }\end{array}$ & 9 & 4.8 & 26 & 7.3 & $>0.05$ \\
\hline $\begin{array}{l}\text { Marriages between } \\
\text { natives of Lutsk } \\
\text { and migrants }\end{array}$ & 27 & 14.4 & 73 & 20.6 & $>0.05$ \\
\hline $\begin{array}{l}\text { Marriages between } \\
\text { migrants }\end{array}$ & 152 & 80.8 & 256 & 72.1 & $<0.01$ \\
\hline $\begin{array}{l}\text { Isolocal marriages } \\
\text { between migrants: }\end{array}$ & 23 & 11.7 & 63 & 17.7 & $>0.05$ \\
\hline $\begin{array}{c}\text {-From the same } \\
\text { village }\end{array}$ & 11 & 5.3 & 27 & 7.6 & $>0.05$ \\
\hline $\begin{array}{l}\text {-From the same } \\
\text { city/town }\end{array}$ & 12 & 6.4 & 36 & 10.1 & $>0.05$ \\
\hline
\end{tabular}

Notes: $f_{1}-$ first generation, $f_{2}-$ second generation, $n$ - number of people, $p$ - significance level

To detect true effects, the data in the Table VII should be supplemented with bigger number of probands and studied on larger samples. The selection indices may show a tendency to decrease in Intermediate and Distant migrations because of a random first effect due to the small number of observations. Therefore, the effect of decreasing of the natural selection pressure in this case may be just a statistical drift.

From the sample of the first generation of natives of Lutsk, one woman was excluded, who was very different from the bulk of the probands, in order to avoid significant shifts in the calculations. She had eight live births and had no pregnancy pathologies. Since this cohort of women includes only 25 people, one such woman gives a strong bias when calculating various statistical criteria. In terms of the number of live births, she was the only woman out of the entire sample of 586 people who had such a number of live births. For example, the next biggest number of children in families was 5 and only met twice through all data.

Although the indicators in the Table VIII did not reach a statistically significant level of differences, we can see the average number of pregnancies and medical abortions among first and second generations of migrants are higher than among the women born in Lutsk. The modal classes in terms of the number of pregnancies are twice as high in the representatives of the second generation to compare with the first one, but the mode for childbirth and live births remains unchanged for all subgroups of the Table VIII. This difference between the number of pregnancies and their positive outcomes can be explained by the number of reproductive losses and the principle of bringing the number of the offspring to the "generally accepted" in society. Unregulated pregnancy outcomes such as miscarriages, stillbirths, and ectopic pregnancies are unchanged in women of all subgroups. Migrants of the first and second generations, on average, have more of live births and childbirths, which means that there is an active influx of genes into Lutsk population.

The number of women who did not have pregnancies remains higher among women classified as migrants in both the first and the second generations compared to natives of Lutsk. Especially pronounced the difference between migrants of the first and the second generation in such 
indicators as "the number of females who did not have pregnancies" and "the number of females who had ectopic pregnancies", which has reached the level of significance ( $p$ $<0.05$, Table IX). The proportion of women who did not give birth in the first generation among the "local" citizens five times higher compared to migrants, this can be explained by wars and revolutions that occurred during the reproductive age of the probands. Many women did not have the opportunity to make a family in those times.

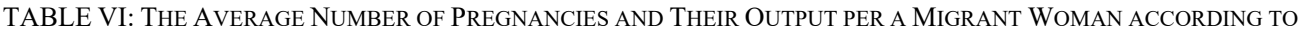
THE MIGRATION DISTANCE

\begin{tabular}{|c|c|c|c|c|c|c|}
\hline \multirow{3}{*}{ Indicators } & \multicolumn{2}{|c|}{ Close Migrations } & \multicolumn{2}{|c|}{ Intermediate Migrations } & \multicolumn{2}{|c|}{ Distant Migrations } \\
\hline & $\begin{array}{c}f_{l} \\
(n=80)\end{array}$ & $\begin{array}{c}f_{2} \\
(n=194)\end{array}$ & $\begin{array}{c}f_{1} \\
(n=62)\end{array}$ & $\begin{array}{c}f_{2} \\
(n=83)\end{array}$ & $\begin{array}{c}f_{l} \\
(n=36)\end{array}$ & $\begin{array}{c}f_{2} \\
(n=28)\end{array}$ \\
\hline & $\bar{x}$ & $\overline{\bar{x}}$ & $\overline{\bar{x}}$ & $\overline{\bar{x}}$ & $\overline{\bar{x}}$ & $\overline{\bar{x}}$ \\
\hline Pregnancies & 3.64 & 3.22 & 3.29 & 3.77 & 4.06 & 3.89 \\
\hline Medical abortions & 1.40 & 1.19 & 1.24 & 1.65 & 1.94 & 1.79 \\
\hline Med. abortions by medical reasons & 0.06 & 0.10 & 0.06 & 0.16 & 0.11 & 0.57 \\
\hline Spontaneous abortions & 0.31 & 0.26 & 0.34 & 0.31 & 0.11 & 0.21 \\
\hline Ectopic pregnancies & 0.03 & 0.04 & 0.02 & 0.06 & 0.03 & 0.07 \\
\hline Stillbirths & 0.05 & 0.03 & 0.03 & 0.02 & - & - \\
\hline Live births & 1.85 & 1.71 & 1.69 & 1.72 & 1.94 & 1.82 \\
\hline Congenital develop. pathologies & 0.03 & 0.01 & 0.02 & 0.07 & 0.06 & 0.07 \\
\hline Childbirths & 1.90 & 1.74 & 1.73 & 1.72 & 1.94 & 1.82 \\
\hline
\end{tabular}

Notes: $n$ - number of probands, $f_{l}-$ first generation, $f_{2}-$ second generation, $\overline{\mathrm{x}}-$ arithmetic mean

TABLE VII: CROW'S INDEXES IN TwO GENERATIONS ACCORDING TO THE MigRATION DiSTANCE

\begin{tabular}{|c|c|c|c|c|c|c|}
\hline \multirow{2}{*}{ Indicators } & \multicolumn{2}{|c|}{ Close Migrations } & \multicolumn{2}{|c|}{ Intermediate Migrations } & \multicolumn{2}{|c|}{ Distant Migrations } \\
\hline & $f_{l}(n=80)$ & $f_{2}(n=194)$ & $f_{l}(n=62)$ & $f_{2}(n=83)$ & $f_{l}(n=36)$ & $f_{2}(n=28)$ \\
\hline $\bar{x}^{2}$ & 3.42 & 2.92 & 2.86 & 2.96 & 3.76 & 3.31 \\
\hline$s^{2}$ & 0.70 & 0.65 & 0.63 & 0.44 & 0.42 & 0.40 \\
\hline$I_{f}=s^{2} / \bar{x}^{2}$ & 0.205 & 0.223 & 0.220 & 0.149 & 0.112 & 0.121 \\
\hline$p_{d}$ & 0.015 & 0.003 & 0.015 & 0.003 & 0.015 & 0.003 \\
\hline$p_{s}$ & 0.985 & 0.997 & 0.985 & 0.997 & 0.985 & 0.997 \\
\hline$I_{m}=p_{d} / p_{s}$ & 0.015 & 0.003 & 0.015 & 0.003 & 0.015 & 0.003 \\
\hline$I_{f} / p_{s}$ & 0.208 & 0.223 & 0.223 & 0.149 & 0.114 & 0.121 \\
\hline$I_{t o t}=I_{m}+I_{f} / p_{s}$ & 0.223 & 0.226 & 0.238 & 0.152 & 0.129 & 0.124 \\
\hline
\end{tabular}

Notes: see Table III

TABLE VIII: The AVERAge Number of PREgnANCIES AND THEIR OUTPUT PER A MigRANT WoMAN ACCORDING TO THE PLACE OF BIRTH

\begin{tabular}{|c|c|c|c|c|c|c|c|c|c|c|c|c|}
\hline \multirow{4}{*}{ Indicators } & \multicolumn{12}{|c|}{ Generations } \\
\hline & \multicolumn{6}{|c|}{$f_{1}$} & \multicolumn{6}{|c|}{$f_{I}$} \\
\hline & \multicolumn{3}{|c|}{$\begin{array}{c}\text { Natives of Lutsk } \\
(\mathrm{n}=24)\end{array}$} & \multicolumn{3}{|c|}{$\begin{array}{c}\text { Migrants } \\
(\mathrm{n}=178)\end{array}$} & \multicolumn{3}{|c|}{$\begin{array}{c}\text { Natives of Lutsk } \\
(\mathrm{n}=77)\end{array}$} & \multicolumn{3}{|c|}{$\begin{array}{c}\text { Migrants } \\
(\mathrm{n}=306)\end{array}$} \\
\hline & $\bar{x}$ & Mo & $M e$ & $\bar{x}$ & Mo & $\mathrm{Me}$ & $\bar{x}$ & Mo & $\mathrm{Me}$ & $\bar{x}$ & Mo & $M e$ \\
\hline Pregnancies & 3.21 & 2.0 & 3.0 & 3.60 & 2.0 & 3.0 & 3.22 & 4.0 & 3.0 & 3.44 & 3.0 & 3.0 \\
\hline Medical abortions & 1.21 & 0.0 & 1.0 & 1.46 & 0.0 & 1.0 & 1.23 & 0.0 & 1.0 & 1.37 & 0.0 & 1.0 \\
\hline $\begin{array}{l}\text { Med. abortions } \\
\text { by medical reasons }\end{array}$ & - & 0.0 & 0.0 & 0.07 & 0.0 & 0.0 & 0.08 & 0.0 & 0.0 & 0.16 & 0.0 & 0.0 \\
\hline Spontaneous abortions & 0.33 & 0.0 & 0.0 & 0.28 & 0.0 & 0.0 & 0.30 & 0.0 & 0.0 & 0.27 & 0.0 & 0.0 \\
\hline Ectopic pregnancies & - & 0.0 & 0.0 & 0.02 & 0.0 & 0.0 & 0.05 & 0.0 & 0.0 & 0.05 & 0.0 & 0.0 \\
\hline Stillbirths & 0.04 & 0.0 & 0.0 & 0.03 & 0.0 & 0.0 & 0.04 & 0.0 & 0.0 & 0.03 & 0.0 & 0.0 \\
\hline Live births & 1.63 & 2.0 & 2.0 & 1.81 & 2.0 & 2.0 & 1.62 & 2.0 & 2.0 & 1.73 & 2.0 & 2.0 \\
\hline $\begin{array}{l}\text { Congenital develop. } \\
\text { pathologies }\end{array}$ & 0.04 & 0.0 & 0.0 & 0.03 & 0.0 & 0.0 & 0.06 & 0.0 & 0.0 & 0.04 & 0.0 & 0.0 \\
\hline Childbirths & 1.67 & 2.0 & 2.0 & 1.85 & 2.0 & 2.0 & 1.66 & 2.0 & 2.0 & 1.75 & 2.0 & 2.0 \\
\hline
\end{tabular}

Notes: see Table I.

Migrants are more often resort to medical abortions (58\% in the first generation and $61 \%$ in the second generation), compared with natives of Lutsk ( $50 \%$ and $52 \%$, respectively). However, the number of spontaneous abortions was noted by $25 \%$ of the "local" population, while among migrants this indicator is lower and placed at the level of $18-19 \%$, respectively. Perhaps this amount is offset by the large number of induced abortions among migrant women. The proportion of women who had ectopic pregnancies statistically significantly differs between the first and second generation of migrants $(2.2 \%$ and $4.6 \%$, respectively). The first generation of natives of Lutsk does not have this indicator, which can be associated with the small number of women in the sample. The proportion of women who had a stillbirth is slightly higher in both generations of "locals" in comparison with migrants. The indicators of artificially terminated pregnancies by women from the vast number of all pregnancies are quite conservative in all groups of the Table IX and is at the level of $38-40 \%$. The indicator of the percentage of realized zygotes is also very similar in the population of Lutsk and varies only from 50 to $51 \%$.

The selection indexes studied in different generations among marriages between natives of Lutsk and migrants do not differ significantly. The high selection rate among the natives of Lutsk can be explained by the small sample and, therefore, the much larger variance in the number of 
offspring, which directly affects the Crow index. In general, these indicators suggest that the selection pressure for the Lutsk population is approximately the same for both local natives and migrants, who mostly come to the city from the same region and replenish the genetic pool of the Lutsk population mainly by genes of Western Ukrainian populations.

TABLE IX: Distribution OF PREgNANCY OUTCOMES IN WOMEN IN TWO GENERATIONS ACCORDING TO THE PLACE OF BIRTH

\begin{tabular}{|c|c|c|c|c|c|}
\hline \multirow{3}{*}{ Indicators } & \multicolumn{4}{|c|}{ Generations } & \multirow{3}{*}{$p$} \\
\hline & \multirow{2}{*}{$\begin{array}{c}f \\
\text { Natives of Lutsk } \\
(n=24)\end{array}$} & \multirow[b]{2}{*}{$\begin{array}{c}\text { Migrants } \\
(n=178)\end{array}$} & \multicolumn{2}{|l|}{$f_{2}$} & \\
\hline & & & $\begin{array}{c}\text { Natives of Lutsk } \\
(n=77)\end{array}$ & $\begin{array}{c}\text { Migrants } \\
(n=306)\end{array}$ & \\
\hline " did not have pregnancies (\%) & 4.2 & 9.6 & 2.6 & 2.0 & $<<0.05$ \\
\hline did not give birth $(\%)$ & 8.3 & 8.4 & 3.9 & 4.9 & $>0.05$ \\
\hline had medical abortions (\%) & 50.0 & 58.4 & 51.9 & 61.1 & $>0.05$ \\
\hline had spontaneous abortions (\%) & 25.0 & 18.0 & 24.7 & 19.3 & $>0.05$ \\
\hline had ectopic pregnancies (\%) & - & 2.2 & 5.2 & 4.6 & $<0.05$ \\
\hline had stillbirth (\%) & 4.2 & 3.4 & 3.9 & 2.6 & $>0.05$ \\
\hline $\begin{array}{c}\text { Artificially terminated } \\
\text { pregnancies }\end{array}$ & 37.7 & 39.0 & 38.3 & 39.9 & $>0.05$ \\
\hline Realized zygotes & 50.6 & 50.4 & 50.4 & 50.2 & $>0.05$ \\
\hline
\end{tabular}

Notes: see Table II.

TABLE X: CROW'S INDEXES IN TWO GENERATIONS ACCORDING TO THE PLACE OF BIRTH

\begin{tabular}{|c|c|c|c|c|}
\hline \multirow[b]{2}{*}{ Indicators } & \multicolumn{2}{|c|}{$\overline{f_{l}}$} & \multicolumn{2}{|l|}{ 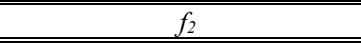 } \\
\hline & $\begin{array}{c}\text { Natives of Lutsk } \\
(n=24)\end{array}$ & $\begin{array}{c}\text { Migrants } \\
(n=178)\end{array}$ & $\begin{array}{c}\text { Natives of Lutsk } \\
(n=24)\end{array}$ & $\begin{array}{c}\text { Migrants } \\
(n=178)\end{array}$ \\
\hline $\bar{x}^{2}$ & 2.66 & 3.28 & 2.62 & 2.99 \\
\hline$s^{2}$ & 0.68 & 0.61 & 0.55 & 0.59 \\
\hline$I_{f}=s^{2} / \bar{x}^{2}$ & 0.256 & 0.186 & 0.210 & 0.197 \\
\hline$p_{d}$ & \multicolumn{2}{|c|}{0.015} & \multicolumn{2}{|c|}{0.003} \\
\hline$p_{s}$ & \multicolumn{2}{|c|}{0.985} & \multicolumn{2}{|c|}{0.997} \\
\hline$I_{m}=p_{d} / p_{s}$ & \multicolumn{2}{|c|}{0.015} & \multicolumn{2}{|c|}{0.003} \\
\hline$I_{f} / p_{s}$ & 0.260 & 0.189 & 0.260 & 0.189 \\
\hline$I_{t o t}=I_{m}+I_{f} / p_{s}$ & 0.275 & 0.204 & 0.275 & 0.204 \\
\hline
\end{tabular}

Notes: see Table III.

\section{CONCLUSIONS}

1. Lutsk population is characterized by a narrowed type of population reproduction, which is typical for all developed countries.

2. Lutsk population has been actively growing throughout the twentieth century due to the high influx of Close migrants.

3. Natural selection indices range from 0.20 for migrants to 0.27 for local natives. In the dynamics of generations, Crow's indexes decrease from the first generation to the second, which corresponds to the relaxation of natural selection in the urban population of developed countries.

4. During the studied period, migration rates were at a high level and indicate intensive urbanization of Lutsk city, but the effectiveness of migration is low, as most migrants come from villages in the Volyn region or adjacent regions of Ukraine.

\section{ACKNOWLEDGMENT}

The authors are grateful to the Acting Chief Physician V.M. Pakharchuk, of the Lutsk Center for Primary Health Care №2, Chief Physician of the Lutsk Center for Primary Health Care I.V. Gnetnev and Acting Chief Physician T.V. Trach, and doctors L.U. Pazuk, G.Ye. Shagalo, Yu.A. Matushko; obstetricians S.P. Girich and L.G. Bondarchuk for assistance in conducting the study, as well as R.V. Volobuev for statistical analysis software.

\section{REFERENCES}

[1] O. L. Kurbatova, "Demographic genetics of urban population," Summary of Doctor's thesis. Rus., The Vavilov Institute of General Genetics, Russian Academy of Sciences, Moscow, 2014.

O. Л. Курбатова, «Демографическая генетика городского населения,»: автореф. дис. д.б.н., Инст. общей генетикиимени Н. И. Вавилова РАН, Москава, 2014.

[2] Ju. P. Altuhov, "Dynamics of population gene pools under anthropogenic influences," Vestnik VOGiS, vol. 8, № 2, pp. 40-59, 2004.

Ю. П. Алтухов, «Динамика генофондов при антропогенных воздействиях», Вестник ВОГиС, Том 8, № 2, с. 40-59, 2004.

[3] M. S. Hrushevsky The History of Ukraine-Rus: In 11 volumes, 12 books. / Editorial board.: P.S. Sokhan (head) and in. Kiev: Nauk. Dumka, 1991, vol. 4, 1993, p. 544.

М. С. Грушевський Історія України-Руси: В 11 т., 12 кн. / Редкол.: П.С. Сохань (голова) та ін. Київ: Наук. думка, 1991, Т. 4, 1993, 544 c.

[4] Ya.Ye. Illiashenko, O. G. Mikhailyuk, R. N. Oksenyuk, History of Cities and Villages of the Ukrainian SSR, Lutsk //: at 26 vol. / P.T. Tronko, Head of the editorial office of the URE AN URSR, Kiev, Volinska oblast volume / I.S. Klimash (head of the editorial board), 1970, pp. 53-90.

Я. Є. Ілляшенко, О. Г. Михайлюк, Р. Н. Оксенюк, Історія міст $i$ сіл Украӥнської РСР, Луцьк // : у 26 т. / П.Т. Тронько, Головна редакція УРЕ АН УРСР, Київ, том Волинська область / I.С. Клімаш (голова редколегії тому), 1970, с.53-90.

[5] State Committee of Statistics of Ukraine.

Державний комітет статистики України http://2001.ukrcensus.gov.ua/results/general/nationality/volyn/.

[6] M. I. Tyaglii, Karaimi / Encyclopedia of History of Ukraine: at 10 volumes / editorial board: V.A. Smoliy (head); Institute of History of Ukraine of the National Academy of Sciences of Ukraine. Kiev: Naukova Dumka, vol. 4, p. 102, 2007. 
М. І. Тяглий, Караӥми / Енииклопедія історії Украӥни: у 10 т. редкол.: В. А. Смолій (голова); Інститут історії України НАН України. Київ: Наукова думка, Т. 4, с. 102, 2007.

[7] L. A. Atramentova, I. P. Meshcheryakova, O. V. Filiptsova, "Reproductive characteristics and the Crow's index in different populations of Evpatoria,” Russian jornal of genetics, Vol. 49, № 12. pp. 1398-1406, 2013.

Л. А. Атраментова, И. П. Мещерякова, О. В. Филипцова, "Репродуктивные характеристики и индекс Кроу в различных группах населения Евпатории,” Генетика, том 49, № 12. с. 1398 1406, 2013.

[8] National Economy of the Ukrainian SSR in 1990: Statistical Yearbook. Ministerstvo statystyky USSR, Kyiv: Tekhnika, p.48, 1991

[9] Statistical Yearbook of Ukraine. Derzhavnyi komitet statystyky Ukraïny. Kyïv: Konsultant, 572 p, 2008.

Статистичний щорічник Украӥни. Державний комітет статистики Украӥни. Київ: Консультант, 572 с, 2008.

[10] N. O. Kozak, L. A Atramentova, "Indexes of natural selection in kharkiv population," Factors in experimental evolution of organisms. Vol. 22, S. 56-61, 2018. DOI: https://doi.org/10.7124/FEEO.v22.924. Н. А. Козак, Л. А. Атраментова, "Показатели естественного отбора в харьковской популяции,” Фактори експериментальної еволюиії організмів, Т. 22, с. 56-61, 2018.

[11] L. A. Atramentova, L. I. Fedchun, S. A. Povolockij, "Differential fertility in the Kharkov population,” Genetika. Vol. 29, № 3. pp. 520 530, 1993. DOI:10.7124/FEEO.v22.924.

Л. А. Атраментова, Л. И. Федчун, С. А. Поволоцкий, “Дифференциальная плодовитость в харьковской популяции,, Генетика, том 29, № 3. с. 520-530, 1993. DOI:10.7124/FEEO.v22.924.

[12] L. A. Atramentova, A. L. Vilker, M. L. Ishchuk, "Differential fertility in the urban populations in Ukraine," Bulletin of problems of biology and mеdicine вісник проблем біології і медииини, Vol 11, p. 42-45, 1999. Вип. 11. С. 42-45.

Л. А. Атраментова, А. Л. Вилькер, М. Л. Ищук, “Дифференциальная плодовитость в городских популяциях Украины," Вісник проблем біологї і медицини, Вип. 11, с. 42-45, 1999.

[13] A. N. Kucher, O. L. Kurbatova, "The population-genetics study of differential fertility in urban population," Genetika, vol. 22, № 2. pp. 304-311, 1986.

А. Н. Кучер, О. Л. Курбатова, "Популяционно-генетическое изучение дифференциальной плодовитости человека в городском населении," Генетика, том 22, № 2. с. 304-311, 1986.

[14] L. A. Mustafaeva, N. A. Kozak, "Vital characteristics of reproduction of Crimean Tatar women," Genetika cheloveka i patologija. Problemy evoljucionnoj mediciny, № 10, p. 57-59, 2014.

Л.А. Мустафаева, Н.А. Козак, "Витальные характеристики репродукции крымскотатарских женщин," Генетика человека $u$ патология. Проблемы эволюциионной медицины, № 10, с. 57-59, 2014.

[15] L. A. Atramentova, L. A. Mustafaeva, "Crow's index in the population of Crimean Tatars," Vestnyk kharkovskoho natsyonalnoho unyversyteta ymeny V.N. Karazyna. Seryia «Byolohyia». Vol. 26. pp. 91-96, 2016. Л.А. Атраментова, Л.А. Мустафаева, “Индексы потенциального отбора в популяции крымских татар”, Вісник Харківського національного університету імені В.Н. Каразіна, серія “Біологія”. Вип. 26, с. 91-96, 2016.

[16] G. I. El'chinova, N. V. Kriventsova, S. S. Amelina, R. A. Zinchenko, "Medical Genetic Study of the Rostov Oblast Population: Changes in Reproductive Parameters with Time," Russian Journal of Genetics, Vol. 40, No. 11, pp. 1305-1307, 2004. Translated from Genetika, Vol. 40, No. 11, pp. 1576-1579, 2004.

[17] O. L. Kurbatova, Ye. Yu. Pobedonostseva, F. R. Gurgenova, K. B. Bulayeva, "Variation of the Parameters of Natural Reproduction and Crow's Index in the Ethnic Groups of Dagestan," Russian journal of genetics, Vol. 48, № 10, pp. 1221-1227, 2012. Translated from Genetika, Vol. 48, № 10, pp. 1221-1227, 2012.

[18] L. A. Atramentova, O. V. Filiptsova, S. Yu. Osipenko, "Genetic and demographic processes in urban populations of Ukraine in the $90 \mathrm{~s}$ Ethnic composition of the migration flow of the Kharkiv population," Genetika, Vol. 38, № 9, pp. 1276-1281, 2012.

Л. А. Атраментова, О. В. Филипцова, С. Ю. Осипенко, "Генетикодемографические процессы в городских популяциях Украины в 90-х годах. Этнический состав миграционного потока харьковской популяции," Генетика, т. 38, №9, с. 1276-1281, 2002.

[19] O. I. Timchenko, E. M. Omel'chenko, Ye. T. Nikula, "Dynamics of marriage structure in three ukrainian cities from 1960 to 1992," Genetika, Vol. 36, № 4, pp. 545 - 551, 2000.
О. И. Тимченко, Е. М. Омельченко, Е. Т. Никула, “Динамика структуры населния трех городов Украины в период с 1960 по 1992 г.," Генетика, т.36., №4, с. 545-551, 2000.

[20] O. L. Kurbatova, E.Yu. Pobedonostseva, E.A. Svezhinsky, "Genetic and demographic processes in the Moscow population in the mid-90s. Migration and emigration as factors of changing the genetic diversity of the population," Genetika, Vol. 33, № 12, pp. 1688 - 1696, 1997. О. Л. Курбатова, Е. Ю. Победоносцева, Е. А. Свежинский, "Генетико-демографические процессы в московской популяции в середине 90-х годов. Миграция и эмиграция как факторы изменения генетического разнообразия популяции," Генетика, т. 33, №12, c. 1688-1696, 1997. 